УДК 94 (73) «1945/1946»

DOI: https://doi.org/10.33782/eminak2019.2(26).297

\title{
ГЕНРІ УОЛЛЕС І ЗАКОНОДАВЧЕ ВРЕГУЛЮВАННЯ КОНТРОЛЮ ЗА ВИКОРИСТАННЯМ ЯДЕРНОЇ ЕНЕРГІЇ В США У 1945-1946 pp.
}

\author{
Віктор Лущак \\ Державна установа «Інститут всесвітньої історії НАН України» (Київ, Україна) \\ e-mail: v.v.lushchak@gmail.com \\ ORCID: https://orcid.org/0000-0003-1142-3271
}

У статті досліджується проблема формування Закону США «Про атомну енергію» 1946 р. під кутом протистояння цивільного та військового підходів до проблеми контролю над атомною енергією. Було встановлено, що природа протистояння пов'язана $з$ різними поглядами на використання атомної енергії у післявоєнний період: для одних інструмент підтримки національної безпеки за рахунок монопольного контролю над атомною зброєю, для інших - джерело небезпеки та фактор, перш за все, економічного розвитку. Розглянуто роль, яку відіграв Генрі Уоллес у недопущенні встановлення військової опіки над атомною енергією.

Ключові слова: атомна енергія, ядерна бомба, «Мангеттенський проект», Комісія 3 атомної енергії США

Одним із найбільших наукових досягнень XX ст. стало відкриття використання атомної енергії для військових і мирних цілей. Уперше й востаннє ядерну зброю було застосовано під час Другої світової війни. Бомбардування японських міст Хіросіми та Нагасакі досі $є$ унікальним випадком використання ядерної зброї у військових цілях, проте загроза «ядерної зими» існувала впродовж всього періоду «холодної війни» i, на жаль, залишається актуальною у наш час.

Організація Об'єднаних Націй, як платформа для міжнародної співпраці та забезпечення миру, через низку причин, що вимагають окремого розгляду, не змогла встановити контроль над атомною енергією та запобігти гонці ядерних озброєнь у повоєнний період. Перші нормативні кроки у напрямку мирного використання атомних технологій і нерозповсюдження ядерної зброї були зроблені урядом США, який ухвалив, у ході широкої суспільно-політичної дискусії, внутрішнє атомне законодавство. Дослідження післявоєнних дебатів у США з приводу долі атомної енергії в мирний час залишається актуальною та недостатньо дослідженою проблемою. Важливим $є$ участь і внесок у розробку Закону США «Про атомну енергію» міністра торгівлі Генрі Уоллеса, ідеї та переконання якого обігнали свій час і відповідають баченню атомної енергії як засобу досягнення економічного процвітання, а не руйнування світу у пеклі термоядерної війни. Метою даної статті є дослідження проблеми формування внутрішнього законодавства США з атомної енергії та ролі у ній г. Уоллеса.

Вплив поглядів Г. Уоллеса на розробку Закону «Про атомну енергію» США не було ще комплексно досліджено ні іноземними, ні вітчизняними істориками, хоча частково висвітлено у працях: Р. Уолтона를 Д. Єргіна², «Критики Холодної війни» під ре-

\footnotetext{
1 Walton R. Henry Wallace, Harry Truman, and the Cold War. NY: The Viking Press, 1976. 388 p.

2 Yergin D. Shattered peace: The origins of the Cold War and the National Security State. Boston: Houghton Mifflin, 1977. 526 p.
} 
дакцією Т. Патерсона 3 , М. Шімамото4. Основу джерельної бази, на яку опирався автор під час написання статті, становлять: щоденник Г.Уоллеса5, матеріали засідання Комітету з антиамериканської діяльностіб, а також матеріали з архіву Г. Уоллеса, що зберігаються у бібліотеці університету штату Айова7.

Витоки атомної політики США відносяться до становлення та діяльності «Мангеттенського проекту», внаслідок реалізації якого були створені перші атомні бомби. Поява американської атомної програми напряму пов'язана з ініціативою науковців і високим рівнем довіри до їхніх ідей президента Ф. Рузвельта. Фізикиіммігранти (А.Ейнштейн, Л.Сілард, Ю.Вігнер, Е.Теллер та ін.), переконали Ф. Рузвельта у необхідності розпочати широкомасштабні дослідження, щоб встановити можливості використання атомної енергії для виробництва бомбия. Як результат, 19 жовтня 1939 р. президент ініціював створення Уранового комітету при Національному бюро стандартів.

Подальша взаємодія науковців і держави відбувалася завдяки активним діям директора Інституту Карнегі доктора Ванневара Буша. Очоливши Управління наукових досліджень і розробок (далі - УНДР) ${ }^{9}$, д-р Буш став головним науковим радником президента Ф. Рузвельта під час Другої світової війни. За вимогою д-ра Буша Урановий комітет став відділом УНДР з урану, під кодовою назвою S-110.

На цьому етапі розгортання американської атомної програми єдиним з політиків адміністрації Ф. Рузвельта, кого було проінформовано про секретні ядерні дослідження, був віце-президент Г. Уоллес, який часто консультував президента з наукових питань. Детально про американські дослідження в галузі атомної енергії Г. Уоллесу розповів у червні 1940 р. В. Буш: «...3 того, що сказав мені д-р Буш, президент, на цих ранніх етапах хотів, щоб ці питання (вивчення можливостей використання U-235 для створення атомної бомби) були обговорені зі мною, оскільки я був другою людиною в команді. Крім того, у президента на той час, я вважаю, була велика довіра щодо мого наукового досвіду»11. Відповідно до зміни ситуації на міжнародній арені та прогресу науковців у дослідженнях, зацікавленість держави в ядерній програмі США зростала. Поштовхом для прискорення робіт стали висновки британського MAUD12, в яких підтверджувалася можливість розробки бомби до закінчення

\footnotetext{
${ }^{3}$ Cold war critics: Alternatives to American foreign policy in the Truman years / Ed. Thomas G. Paterson. Chicago: Quadrangle Books, 1971.313 p.

4 Shimamoto M. Henry A. Wallace's Criticism of America's Atomic Monopoly, 1945-1948. UK: Cambridge Scholars Publishing, 2016. 225 p.

5 The Price of Vision: The Diary of Henry A. Wallace 1942-1946 / Ed. John Morton Blum. NY: Houghton Mifflin, $1973.707 \mathrm{p}$.

${ }^{6}$ Hearings before the Committee on unamerican activities House of Representatives. Vol. I. Washington: United States government printing office, $1950.1120 \mathrm{p}$.

7 The University of Iowa Libraries. Henry A. Wallace Collection. офіційна сторінка. URL: http://wallace.lib.uiowa.edu/

8 Вченим було відомо, що у Третьому Рейху велись серйозні дослідження у цьому напрямку, зокрема, нацистами було взято під контроль уранові поклади на території колишньої Чехословаччини. На час війни було відомо ще два місцезнаходження урану - у Бельгійському Конго й у Канаді.

9 Управління наукових досліджень і розробок було засновано 28 червня 1941 р. (через 6 днів після нападу Німеччини на СРСР) та взяло на себе функції координації та реалізації наукових проектів для потреб національної оборони.

${ }^{10}$ Hewlett R. The New World. 1939-1946. Pennsylvania: Pennsylvania State University Press, 1962. P. 155.

11 Hearings before the Committee on unamerican activities House of Representatives... P. 1074.

12 MAUD (Військове застосування детонації урану) - назва британського комітету, в якому англій-
} 
війни.

У червні 1942 р.13, американський атомний проект, з погодження президента, перейшов з наукового етапу в стадію практичного втілення та був переданий під контроль військових ${ }^{14}$. 3 цього часу Г. Уоллес був відсторонений від участі у роботі проекту, його управлінський талант був спрямований на перевлаштування економіки країни на потреби досягнення перемоги у війні: «...усе, що я хотів знати це те, що робота просувається. Я не знав ні назви проекту, ні місця розташування, але я припускав, що д-р Буш робить свою роботу» ${ }^{15}$. 3 переходом у 1942 р. американської атомної програми під контроль військового відомства відбулося засекречення всіх матеріалів і результатів діяльності у рамках «Мангеттенського проекту». Питання нерозголошення даних про стан ядерних досліджень до закінчення війни було погоджено на зустрічах Ф. Рузвельтом і В. Черчиллем у Квебеці (1943 р.) та Гайд Парку (1944р.).

Президент Ф. Рузвельт не дожив до початку атомної ери ${ }^{16}$, а для його наступника Г. Трумена стало несподіванкою, що такі масштабні роботи із залученням армії й уряду не були доведені до його відома як віце-президента 17 , що, у черговий раз, доводить найвищий рівень секретності атомного проекту. Президент Г. Трумен використав ядерну зброю, відповідно до тих цілей, які переслідував його попередник пришвидшити капітуляцію Японії та переможно закінчити Другу світову війну. Як результат, після бомбардувань Хіросіми та Нагасакі, у ході яких було продемонстровано руйнівні можливості атомної енергії, завісу секретності щодо англо-американоканадських ядерних досліджень для світового загалу було піднято, що відкривало шлях для встановлення міжнародного контролю над таким небезпечним для цивілізації джерелом енергії та використання його для мирних цілей.

Проблема контролю над атомною зброєю та ядерною енергією, яка вийшла за рамки внутрішнього американського дискурсу, стала першим серйозним викликом для ще одного великого проекту Ф. Рузвельта - Організації Об'єднаних Націй, яка засновувалась як міжнародна платформа, де в рамках багатосторонньої співпраці повинні вирішуватись важливі для підтримання миру та безпеки питання. Із капітуляцією Японії адміністрація Г. Трумена розпочала формувати американську політику в галузі атомної енергії. Центральне питання, яке викликало широку суспільнополітичну дискусію, і було напряму пов'язане із подальшими кроками США у своїй внутрішній і зовнішній атомній політиці - можливість надання міжнародному товариству інформації з ядерної енергї.

Обговорення на політичному рівні питання обміну науковими знаннями з атом-

ські та німецькі вчені працювали над першою у світі атомною бомбою. Створений комітет у квітні 1940 р. На основі роботи комітету було створено британську ядерну програму - «Tube Alloys». 13 Ф.Рузвельт санкціонував розгортання повномасштабних робіт зі створенню бомби 17 червня 1942 р., затвердивши проект робіт підготовлений В.Бушем і Дж. Конантом та попередньо затверджений Г. Уоллесом і генералом Дж. Маршалом.

1413 серпня 1942 р. в Нью-Йорку був створений штаб Північно-Атлантичного дивізіону Інженерних військ Армії США під кодовою назвою «Мангеттенський інженерний округ», очолюваний генералом Дж. Маршалом. На базі округу розгорнувся «Манхеттенський проект», керівником 17 вересня 1942 р. був призначений Леслі Гровс.

15 Hearings before the Committee on unamerican activities House of Representatives... P. 1075.

1612 квітня 1945 р. Ф. Рузвельт помер. Його наступником за Конституцією США до наступних виборів став віце-президент Г. Трумен.

17 Г. Трумен був віце-президентом США 82 дні (з 20 лютого 1945 по 12 квітня 1945 р.) і за цей час усього двічі зустрічався з президентом Рузвельтом, який не відкрив йому таємниці Мангеттенського проекту. 
ної енергії відбулося на спеціальному засіданні кабінету міністрів 21 вересня 1945 р. Військовий міністр Г. Стімсон, який був занепокоєний діями президента Г. Трумена у Потсдамі та держсекретаря Дж. Бірнса у Лондоні (намаганням залякати СРСР ядерною бомбою. - Aвт.), запропонував розпочати прямий діалог із Радянським Союзом для обміну знаннями пов'язаними з атомними технологіями, щоб запобігти гонці озброєнь. Навколо цієї пропозиції розпочалася тривала дискусія, яка завдяки пресі вийшла за рамки політичного обговорення. Член адміністрації Г.Уоллес, будучи переконаним у тому, що наукові знання не можуть утримуватися у кордонах однієї держави, підтримав ініціативу військового міністра Г. Стімсона 18.

Аргументи опонентів пропозиції Г. Стімсона, які вірили у те, що атомні секрети повинні й надалі залишатися національним надбанням США, хоча й мали підтримку громадської думки, базувалися на «колективній відсутності наукового розуміння атомної енергї̈» ${ }^{19}$. Ї̈̈ можна пояснити тим, що ядерна фізика на період закінчення Другої світової війни залишалася маловідомою широкому загалу галуззю науки, а основний обсяг інформації пов'язаний із нею до бомбардування японських міст, знаходився під грифом «секретно». У зв'язку з цим, досить часто коли питання стояло про обмін базової інформації з атомної енергії, як у пересічних громадян, так і в політиків, воно асоціювалось 3 наданням іншим державам секретів виробництва атомної бомби.

До того ж, політики та військові не були достатньо проінформовані про розвиток атомних технологій у світі, і тому скептично ставилися до можливості того, що СРСР найближчим часом виготовлять власну атомну бомбу (для прикладу, Л. Гровс відводив СРСР на це щонайменше 20 років) ${ }^{20}$. Хоча Радянський Союз був спроможним створити ядерну зброю набагато швидше, на чому наголошував і міністр Уоллес: «У даний час із публікацією «звіту Сміта» 21 й іншою наявною інформацією немає суттєвих наукових секретів, які могли б стати перешкодою для виробництва атомної бомби іншими державами»22. Тому збереження атомної монополії США, яку підтримувала велика частина, так званих, «полісімейкерів» в адміністрації президента була, за влучним визначенням вчених і згодом підхопленим Г. Уоллесом, помилковою надією на безпеку «за науковою лінією Мажино»23.

Важливим чинником на який не могла не звертати уваги адміністрація Трумена, при вирішенні такого важливого для майбутнього країни та світу питання, була суспільна думка. Більшість пересічних громадян США та ЗМІ підтримувало ідею контролю ООН над атомною енергією. Але, разом з тим, американців вважали, що до того, як буде встановлена ефективна система міжнародного контролю та інспекцій, Сполучені Штати повинні зберігати ядерну монополію.

Уряду США довелося маневрувати, враховуючи задекларовані попередньою адміністрацією міжнародні зобов'язання та внутрішньополітичну ситуацію. 8жовтня 1945 р. Трумен публічно повідомив про своє рішення, де чітко визначив, що американська держава буде прагнути міжнародного контролю над атомною енергією, а

\footnotetext{
18 The Price of Vision... P. 482.

${ }^{19}$ Shimamoto M. Op. cit. P. 69.

20 Yergin D. Op. cit. P. 268.

21 Після бомбардування японських міст у США, з дозволу сенату, було видано книгу Г. Сміта «Атомна енергія для військових цілей». Це була розсекречена інформація щодо розділення ізотопів урану, ядерних реакторів, і в загальних рисах щодо будови атомної бомби.

22 The Price of Vision... P. 486.

23 Walton R. Op. cit. P. 56.
} 
щодо секретів ядерної зброї, то вони зберігатимуться США доти, доки ООН не буде створена дієва система контролю. Заява президента визначила основний курс США у внутрішній і зовнішній атомній політиці. Ця позиція, та задекларована ${ }^{24}$ необхідність використання атомної енергії виключно в мирних цілях, на нашу думку, і стали дороговказом для формування закону США з атомної енергії.

Головним «підводним каменем» у процесі розробки американського законодавства з атомної енергії стало питання постійного контролю над ядерними дослідженнями та розробками. У цій дискусії проявилося дві точки зору на застосування атомного потенціалу. Перша - мирне використання у промислових цілях, яке не потребує участі військових і передбачає цивільний контроль над атомною програмою, - його відстоював Г.Уоллес, низка науковців і політики прогресисти. Друга - забезпечення національної безпеки через збереження атомної монополії, що вимагає продовження військового контролю, найактивніше цю позицію відстоював керівник Мангеттенського проекту Л. Гровс.

Під час розмов із президентом Г. Труменом міністр Уоллес неодноразово висловлював своє занепокоєння тим, що американський атомний арсенал і матеріали для виробництва атомних бомб продовжують перебувати під керівництвом Л. Гровса, який публічно заявляв про те, що мирне використання атомної енергії неможливе ще протягом багатьох років, що не відповідало реальному стану речей 25.

Позицію Л.Гровса підтримували впливові військові (Дж. Форрестал, Р. Паттерсон) і цивільні політики вищого ешелону (Дж. Бірнс, А. Ванденберг). Саме за сприяння А. Ванденберга у жовтні 1945 р. був внесений до розгляду в Палату представників перший проект закону, що регулював внутрішнє законодавство з питань атомної енергії - «законопроект Мей-Джонсона»26. Хоча автори та прихильники законопроекту стверджували, що він був розроблений, щоб замінити військовий нагляд цивільним контролем, але окремі його положення суперечили їх заявам: в Комісії з атомної енергії (далі - КАЕ) з 9 членів 4 мали бути військовослужбовцями; не було передбачено ніяких асигнувань на розвиток і дослідження атомної енергії у мирних цілях; продовжувалася політика секретності досліджень і передбачалася система покарань за її недотримання й ін. За висловом історика Р. Х'юлетта «даний біль був розроблений, щоб використовувати атомний потенціал для сприяння подальшим військовим розробкам» ${ }^{27}$.

Авторитетні вчені, 3MI 28 , політики різних рангів (Г. Сміт - директор бюджетного управління, Г.Ікес - міністр внутрішніх справ, Г.Уоллес - міністр торгівлі, Дж. Снайдер та ін.) виступили категорично проти «законопроекту Мей-Джонсона». Завдяки їхнім протестам, швидке просування даного проекту закону з атомної енергії було призупинено та відправлено на доопрацювання. Для цих цілей, наприкінці жовтня 1945 р., Сенат сформував Спеціальний комітет з атомної енергії, який очолив сенатор Б. Макмагон.

\footnotetext{
2411 листопада 1945 р. у Вашингтоні Г. Трумен зустрівся з британським прем'єр-міністром Клементом Еттлі і з канадським прем'єр-міністром Маккензі Кінгом, на якій вирішувались питання подальшої долі атомної енергії у мирний час.

25 Walton R. Op. cit. P. 70.

26 У червні 1945 р. Тимчасовий комітет, очолюваний Г. Стімсоном, доручив Дж. Гаррісону (заступник Г. Стімсона та член комітету) підготувати законодавство з атомного питання.

27 Hewlett R. Op. cit. P. 196.

28 Газета «The Chicago Sun» у заголовку до статті звинуватила військовий департамент у спробі «провести законодавство через Конгрес».
} 
Міністр Уоллес брав активну участь в обговорені рекомендацій про внесення змін до законопроекту та разом із Управлінням військової мобілізації та реконверсії (далі - УВМР) на чолі з Джоном Снайдером ${ }^{29}$ розробив пропозиції, спрямовані на обмеження діяльності КАЕ президентом і Конгресом США, а також зменшення ролі військових ${ }^{30}$. Результати роботи Г. Уоллес передав президенту Г. Трумену особисто: «У світлі того, що атомна енергія може вплинути на наше економічне, соціальне та політичне життя, наголошую на важливості внесення змін до законопроекту, відповідно до рекомендацій УВМР»31. Упродовж листопада та більшої частини грудня 1945 р. проходили слухання Спеціального комітету Сенату з атомної енергії, який дійшов висновку про те, що через велику кількість необхідних змін, доцільно розпочати підготовку нового законопроекту («законопроект Макмагона»), до якого, у підсумку, були внесені рекомендації підготовлені Г. Уоллесом та УВМР.

На формування положення про інформаційну політику, окрім тиску зі сторони військово-промислових кіл та ультрапатріотичних організацій (які наполягали на секретності), суттєво вплинуло загострення міжнародної напруги на початку 1946 р., яка була пов'язана з різного роду заявами: промова Й. Сталіна у Великому театрі, «довга телеграма» Кеннана, фултонська промова В. Черчилля. Ці обставини йшли у розріз із пропозиціями розсекречення та встановлення вільного обміну ядерною інформацією.

Останнім аргументом на користь збереження секретності став випадок пов'язаний з радянськими шпигунами, яких у лютому 1946 р. було затримано у Канаді, так звана, «справа Гузенка». Цей епізод посилив позиції військових, особливо Р. Паттерсона та Л. Гровса, які переконували у тому, що збереження секретності вимагає участі військових, наділених відповідними повноваженнями ${ }^{32}$. У підсумку, сенат переписав розділ законопроекту «Про розповсюдження інформації», замінивши його на «Контроль інформації»: встановлювалась заборона на обмін інформацією 3 іншими країнами, у тому числі з союзними, як на військове, так і на мирне використання атомної енергії33. Г. Уоллес рекомендував президенту Трумену обмежити секретність винятково ядерною зброєю, а дослідження та використання атомної енергії у промислових цілях пропонував передати в руки приватному бізнесу. Але пропозиції міністра Уоллеса та застереження низки вчених не були взяті до уваги. Пункти про повну секретність інформації стали у майбутньому положенням закону, що призвело до припинення співпраці США та Великобританії у сфері ядерних досліджень.

Черговий крок у напрямку збільшення військового впливу в КАЕ був здійснений через пропозицію прийняти поправку Ванденберга ${ }^{34}$, яка фактично надавала б вій-

\footnotetext{
29 УВМР долучилось до розробки законопроекту за рішенням президента.

30 1) Директор комісії має бути поставлений під контроль президента; 2) У законопроекті повинні бути передбачені положення, які дозволять президенту звільняти членів комісії, коли він буде вважати це необхідним у національних інтересах; 3) Для відповідності демократичним принципам ні директор, ні інші члени комісії не повинні бути діючими членами збройних сил; 4) Повна націоналізація виробництва, переробки та володіння матеріалами розчеплення.

31 The Price of Vision... P. 511.

32 Ibid. P. 570.

${ }^{33}$ Atomic Energy Act of 1946. Washington: U. S. Atomic Energy Commission, 1965. P. 12.

34 При КАЕ мав створюватися Військовий комітет зв'язку. Комітет мали інформувати з усіх питаннях ядерних досліджень, які, на думку комітету, відносилися до національно оборони. Комітет міг звернутись із проханням до президента скасувати рішення комісії, якщо ці дії комітет вважатиме шкідливими для національної безпеки.
} 
ськовим можливість накладати вето на рішення комісії. У Спеціальному комітеті з атомної енергії поправка отримала серйозну підтримку. Натомість Г. Уоллес відреагував на неї доволі різко, затаврувавши це як «шлях до фашизму» та публічно закликав проти «передачі нації в руки військових», посилаючись на одну із демократичних основ американського суспільства - цивільний контроль над збройними силами⒌ Протести викликали значну суспільну опозицію поправці, достатню, щоб досягнути компромісу. Г. Уоллес запропонував залучити в якості посередника у цьому питанні Д. Ейзенхауера, який розділяв необхідність мирного використання атомної енергії та міг посприяти, за Г.Уоллесом, прийняттю правильних рішень. Зрештою, «поправка Ванденберга» була прийнята, але з суттєвими обмеженнями ролі Комітету зв'язку з військовими у КАЕ, який став у підсумку одним із консультативних органів при комісії.

Л. Гровс виступав проти нового проекту закону, посилаючись на слабкі безпекові положення. I все ж «законопроект Макмагона» був схвалений Сенатом (1 червня), Палатою Представників (20 липня) та підписаний президентом Труменом 1 серпня 1946 р. Згідно з законом, починаючи з 1 січня 1947 р. вся робота над американською атомною програмою, яка перебувала з часів війни під контролем військових, переходила до Комісії з атомної енергії, яка складалась з цивільних осіб, що відповідало прагненням встановити міжнародний контроль над атомною енергією.

Таким чином, дослідження проблеми формування Закону США «Про атомну енергію» 1946 р., під кутом протистояння цивільного та військового підходів щодо питання контролю над атомною енергією, дозволяє зробити наступні висновки:

1. Розробка внутрішнього законодавства з атомної енергії відбувалась у контексті прийнятого адміністрацією Трумена зовнішньополітичного курсу США щодо атомної політики.

2. Природа протистояння цивільного та військового підходів пов'язана з різними поглядами на використання атомної енергї у післявоєнний період: для одних - інструмент підтримання національної безпеки за рахунок монопольного контролю над атомною зброєю, для інших - джерело небезпеки та фактор, перш за все, економічного розвитку.

3. Важливу роль у недопущенні встановлення військової опіки над атомною енергією відіграв Г. Уоллес. Прихильник прогресивістських поглядів, Г. Уоллес користувався авторитетом серед вчених і ліберальних політиків, до того ж, міністр Уоллес був єдиним з адміністрації Рузвельта, хто стояв біля витоків програми ядерних досліджень у США, що дозволило йому швидко зорієнтуватись у дебатах навколо атомної проблеми. Завдяки зусиллям Г.Уоллеса вдалося вивести цю проблему на рівень публічної дискусії й у підсумку не допустити прийняття закону, який запобіг би мирному використанню атомної енергії.

4. Збереження контролю над атомними знаннями означало продовження американської атомної монополії, що мотивувало СРСР прискорити виробництво власної бомби, а Великобританію реанімувати власний атомний проект. Як підсумок, у 1949 р. Радянський Союз, а в 1952 р. Великобританія випробували власні ядерні бомби, що символізувало закінчення атомної монополії США, не дивлячись на застереження Г. Уоллеса та низки науковців.

35 Cold war critics...P. 84-85. 


\section{REFERENCES}

Hewlett, R. (1962). The New World. 1939-1946. University Park, Pennsylvania: Pennsylvania State University Press.

Shimamoto, M. (2016). Henry A. Wallace's Criticism of America's Atomic Monopoly 1945-1948. UK: Cambridge Scholars Publishing.

Thomas, G.P. (Ed.). (1971). Cold war critics: Alternatives to American foreign policy in the Truman years. Chicago: Quadrangle Books.

Walton, R.J. (1976). Henry Wallace, Harry Truman, and the Cold War. NY: The Viking Press.

Yergin, D. (1977). Shattered peace: The origins of the Cold War and the National Security State. Boston: Houghton Mifflin.

\section{Viktor Lushchak}

(The State Institution «Institute of World History of the National Academy of Sciences of Ukraine», Kyiv, Ukraine)

ORCID: https://orcid.org/0000-0003-1142-3271

\section{Henry Wallace and the Legislative Settlement of Control the Use of Atomic Energy in the USA in 1945-1946}

The paper examines the problem of the formation of the US «Atomic Energy Act» of 1946, from the point of view of confrontation between civilian and military approaches to the issue of controlling atomic energy.

The author found out that the main «underwater stone» in the process of drafting the American legislation on nu atomic clear energy was the issue of full-time control over nuclear research and development. In that discussion, there were two points of view on the application of atomic potential. The first was peacetime use for industrial purposes, which did not require military involvement, and set civilian control over the atomic program - a number of scientists and progressive politicians supported it. The second was the safeguarding of national security through the preservation of an atomic monopoly which required the continuation of military control, the most actively that position was maintained by the Director of the «Manhattan Project» L. Groves.

The contribution of US Secretary of Commerce Henry Wallace to prevent the establishment of military custody over atomic energy is characterized. A supporter of progressive views G. Wallace enjoyed the authority of scientists and liberal politicians, besides, Wallace was the only member of Roosevelt's administration who was the architect of the US nuclear research program, and that allowed him to pattern his behavior on the debate over the nuclear problem. The author has proved that thanks to G. Wallace's efforts, this problem was brought to a level of public debate and eventually a law that would prevent the peacetime development of atomic energy was not passed.

Keywords: atomic energy, nuclear bomb, «Manhattan Project», US Atomic Energy Commission 